\title{
THE EFFECT OF COMPETITIVE ADVANTAGE AND HUMAN ADVANTAGE ON INDUSTRIAL COMPETITIVE STRATEGY (Case Study: SMIs in Gorontalo Province)
}

\author{
Trifandi Lasalewo \\ Faculty of Engineering, Universitas Negeri Gorontalo, Indonesia \\ (trifandilasalewo@gmail.com) \\ Nur Aini Masruroh \\ Faculty of Engineering, Universitas Gadjah Mada, Indonesia \\ (aini@ugm.ac.id) \\ Subagyo \\ Faculty of Engineering, Universitas Gadjah Mada, Indonesia \\ (subagyo@ugm.ac.id)

\section{Budi Hartono} \\ Faculty of Engineering, Universitas Gadjah Mada, Indonesia \\ (boed@gadjahmada.edu) \\ Hari Agung Yuniarto \\ Faculty of Engineering, Universitas Gadjah Mada, Indonesia \\ (h.a.yuniarto@ugm.ac.id)
}

\begin{abstract}
Small and Medium Industries (SMIs) have a strategic role in the Indonesian economy, as they earn 61.9 percent of the foreign exchange which goes to make up the nation's Gross Domestic Product, and nationally they are able to absorb 97 percent of the workforce. The Global Competitiveness Report also notes that SMIs serve as the business units that affect every nation's competitiveness. Considering this strategic role, the selection of a competitive strategy for these SMIs is absolutely necessary. Through an in-depth literature review, this study aims to explore what variables influence the competitive strategy of industries, particularly the SMIs. By using a Systematic Literature Review (SLR) with a total of 31 main literature (articles, papers and books), this study has found two dominant factors that influence industrial competitive strategy: Competitive advantage and human advantage, which are subsequently developed into six independent variables (construct variables), i.e. cost, delivery, product quality, product variety, know-how and innovativeness, with a total of 44 indicators. The results of measurements of the sample of SMIs in Gorontalo Province, using Structural Equation Modeling, found that both competitive advantage and human advantage jointly influence 40.2 percent of the industrial competitive strategies. These results indicate that competitive strategies, such as creating products with unique features, on-time delivery, flexibility in production, and employee involvement in the innovations, are indispensable to SMIs in order for them to produce quality products and be able to maintain their advantage.
\end{abstract}

Keywords: industrial strategy, SMIs, competitive advantage, human advantage 


\section{INTRODUCTION}

The Small and Medium Industries (SMIs) sector is an important sector which affects the economies of nations. This sector has a strategic impact on the competitiveness of certain areas globally, and is able to absorb more labor than the larger industries (Tambunan, 2007). For Indonesia, SMIs have a significant effect, because this sector is able to accommodate 97 percent of the workforce; and SMIs contribute 57 percent to the national growth rate (Indonesian Ministry of Cooperatives and SMEs, 2012). The SMI sector also contributes to increasing the Gross Domestic Product (GDP) and generates significant mounts of foreign exchange. For example, in 2011 SMIs contributed 61.9 percent to the Indonesian GDP through tax payments, while the large business sectors only contributed 38.1 percent through their tax payments (Sudaryanto et al., 2014).

As a sector that affects the competitiveness of a region, the development of SMIs receives serious attention in almost every country, because it affects the level of national competitiveness, which is measured using the parameters of the GCI (Global Competitiveness Index). Based on the Global Competitiveness Report 2014-2015, the most competitive country is Switzerland with a GCI score of 5.70 (scale 1-7), followed by Singapore, the United States, Finland, and Germany, while Indonesia ranks 34 th out of the 144 countries surveyed. The competitiveness survey employs twelve criteria, including institutions, infrastructure, the macroeconomic environment, businesses' sophistication, and innovation (World Economic Forum, 2015).

Considering the strategic role of SMIs in a region/country, the selection of appropriate strategies is absolutely necessary. On the other hand, the development of SMIs is constrained by several things, including: (1) SMIs are only able to penetrate niche markets, so the profit they earn is very low; (2) limitations on their management issues; and (3) the lack of a strategy for their businesses' development (Smith \& Smith, 2007). The implementation of an effective and measurable strategy will affect the direction of their development because the company/industry's strategy will affect the policy's priorities, the processes of production, human resources' development, culture, and the technology to be used (Mckeown \& Philip, 2003). A company's strategy will increase its performance (Takala et al., 2007). A company's strategy, in the context of its manufacturing strategy, can contribute to reducing costs, improving quality, providing clear resources, and direct the future of the business's objectives (Dangayach \& Deshmukh, 2001; Laosirihongthong \& Dangayach, 2005).

In much of the literature about industrial policy strategy, particularly for SMIs, it is always associated with the competitive advantage, in addition to the human advantage. The relationship between competitive advantage and industrial competitive strategy is explicitly explained in Porter's (1998) generic strategies which focused on three main aspects, i.e. cost, differentiation, and other focuses. According to Barad \& Gien (2001), strategy is demonstrated through a model that combines both competitive advantage and human advantage aspects, and their impact on the strategic priorities of the SMI's development. Barad and Gien's (2001) research samples were SMIs in the European Community, and they aimed to find out the consumers' priority needs for SMI's products, and the SMI's performance improvement strategies. The research by Barad and Gien's (2001) used five variables, i.e. price, delivery, quality, product variety, and employees' involvement.

Unlike Porter's (1998) generic strategies, which only emphasized the aspects of a company's competitive strength, the researchers studying the aspects of the humanities (e.g. Barad \& Gien, 2001) believe that the involvement of human elements will affect a company's development strategy, so as to make it more comprehensive. The role of human resources is closely related to a product development team's ability to innovate new products which meet consumers' expectations and needs. Human involvement is particularly noticeable in the process of communication with an innovator team, which is made across the company's 
functions, creating certain features expected by the consumers. Such an activity can be seen from the initial idea or concept through to the product's launch on the market (Lasalewo et al., 2015).

Due to the many variables which are involved in and influence the policy's strategy, as well as the limited company resources, it is necessary to identify and determine the priorities of the variables that become the focus of corporate strategy (Takala et al., 2007; Gonzalez \& Vazquez, 2007). The determination of such priorities will direct corporate strategic policy, mainly in dealing with the consequences of the measures taken.

Based on the literature review, there are many variables involved in the research into corporate strategy. The most dominant variables include competitive advantage and human advantage. This paper identifies the manifest variables (indicators) which serve as the variable group for competitive advantage and the variable group for human advantage, as well as investigating the influence of these variables on the industrial competitive strategy (especially in SMIs), hereinafter referred to as the industrial strategy variable. Those serving as the sample and analysis unit in this study were SMIs (small and medium industries) in Gorontalo Province.

\section{REVIEW OF SMIS, MODEL DEVELOPMENT, AND RESEARCH HYPOTHESES}

\section{Small and Medium Industries (SMIs)}

The SMI sector is an important sector for the economy of Indonesia because it accounts for the highest number of enterprises in the country (55.21 million units or 99 percent of the total national enterprises) and provides employment for 79 million workers (Indonesian Ministry of Cooperatives and SMEs, 2012).

SMIs are defined differently in each country and each institution, but generally, the term refers to the amount of labor or the value of the investment in them, or even both (Dangayach \& Deshmukh, 2005). The criteria for SMIs, based on the institutions and the countries are presented in Table 1 and Table 2.

The SMI criteria employed in this study refers to those adapted from the Indonesian Central Statistics Agency (BPS RI), i.e. industries with a maximum number of 99 employees (Lasalewo, 2012).

\section{Competitive Advantage}

A company/industry is said to have a competitive advantage when it has characteristics or attributes that are not owned by its competitors, it does something better than its competitors, or is able to do something that cannot be done by other industries in the same market (Porter, 1998). Through this advantage, an industry/company is capable of understanding the changes to their market's structure and choosing an effective marketing strategy, in which a competitive advantage is obtained when an attempt at developing or acquiring a set of attributes (or executing an action) leads a company to outperform its competitors (Wang, 2014).

Table 1. The Criteria for SMIs Based on the Institutions (Lasalewo, 2012)

\begin{tabular}{llcl}
\hline \multicolumn{1}{c}{ Institution } & \multicolumn{1}{c}{ Type } & $\begin{array}{c}\text { Number of } \\
\text { Employees }\end{array}$ & \multicolumn{1}{c}{ Funding } \\
\hline Indonesian Central Bureau of & Small industries & $5-9$ & - \\
Statistics & Medium industries & $20-99$ & - \\
The Republic of Indonesia Act & Small industries & - & $\begin{array}{l}\text { Assets of IDR 200,000,000; Turnover } \\
\text { of IDR 1,000,000,000/year }\end{array}$ \\
$\begin{array}{l}\text { No. 9/1995 } \\
\text { Indonesian Chamber of }\end{array}$ & Small enterprises & - & $\begin{array}{l}\text { Turnover of IDR 600,000,000 - } \\
\text { Commerce and Industry (Kadin) }\end{array}$ \\
Small Business Administration & Small industries & $<500$ & $1,000,000,000$ \\
\hline
\end{tabular}


Table 2. Criteria for SMIs in Various Countries (Dangayach \& Deshmukh, 2005)

\begin{tabular}{llll}
\hline \multicolumn{1}{c}{ Category } & \multicolumn{1}{c}{ Country } & \multicolumn{1}{c}{ Industry Category } & \multicolumn{1}{c}{ Criteria } \\
\hline Developed & Australia & Manufacturing services & $<100$ employees \\
Countries & & & $<20$ employees \\
& Germany & SMIs & $<500$ employees \\
& France & SMIs & $10-49$ employees \\
& Japan & Manufacture & $<200$ employees \\
& Canada & Manufacture & $<200$ employees \\
& USA & Micro industries & $<20$ employees \\
& & Small industries & $20-99$ employees \\
Developing & China & Medium industries & $100-499$ employees \\
Countries & SMIs & 100 employees \\
& Indonesia & SMIs & Investment of US\$ 8 million \\
& Malaysia & SMIs & $<100$ employees \\
& & & $<175$ employees (full time) \\
& & Investment of US\$ 1 Million \\
Developing & Thailand & Labor intensive & $<200$ employees \\
Countries & & Capital intensive & $<100$ employees \\
& India & SMIs & Max. of 10 million (factory \& \\
& & & machinery/equipment)
\end{tabular}

A competitive advantage is the heart of performance in market competition because the competition is at the core of the success or failure of an enterprise. Competition determines the accuracy of the activities that contribute to the company's performance, such as innovation, a cohesive culture, or a good implementation (Porter, 1998). In their development, theories about competitive advantage have caught researchers' attention for more than half a century (Wang, 2014).

A competitive advantage is always associated with a management strategy, which is defined as the set of decisions and actions resulting in the formulation and implementation of strategies designed to achieve the objectives of an organization (Wang, 2014). Competitive advantages adopt much of Porter's (1998) generic strategies, including (1) cost (concerned with the industry's ability to produce products at a lower cost than the competitors, making it possible to control the price); (2) differentiation (concerning with the ability to create products which are unique and not owned by the competitors); and (3) focuses (concerned with the desire of producers to satisfy the consumers' expectations and needs for the products).

Many researchers have developed Porter's (1998) generic strategies into other forms. For instance, Barad \& Gien (2001) employ four competitive advantage variables, including price (low), delivery (fast, dependable), quality (high design quality, consistent product quality), and variety (high). Phusavat and Kanchana (2007) employ six variables, including (1) quality (lowdefect rate, reliability, product performance, certification, environmental consideration); (2) cost (continuous improvement, quality cost, activity-based measurement, value added, low cost); (3) delivery (dependable promises, right quality, right amount, at the agreed time, fast delivery); (4) flexibility (broad product line, volume changes, design adjustment, mix changes); (5) customer focus (dependable promises, product customization, measurement of satisfaction, after-sale service, product support, customer information); and (6) knowhow (mix changes, training/education, continuous learning, problem solving skills, knowledge management, creativity). 
A competitive advantage can be measured using 12 (twelve) variables, including conformance quality, delivery speed, dependable delivery, design changes, low cost, new product introduction, product customization, product durability, product mix changes, product performance, product reliability and volume changes (Laosirihongthong \& Dangayach, 2005). The results of a study by Laosirihongthong and Dangayach (2005) suggest that the competitive advantage in developed countries is applied through product improvements, improvements to the processes' quality, and timely delivery. An important process in achieving industrial excellence is to maintain the quality and implement efficiencies.

A study by Takala et al. (2007) confirms that a competitive advantage must be supported by a strategy that fits the market being served. The success of this strategy is evidenced by industries in China. Through a low-cost strategy, Chinese industries have become world-class enterprises.

\section{Human Advantage}

In addition to gaining a competitive advantage, an industrial development strategy is also influenced by the advantages of the available human resources. The advantage and involvement of the human element (human advantage) will influence the decision about the strategic priorities of an industrial company (Barad \& Gien, 2001). The strategy and structure of an industry (especially SMIs) is strongly influenced by the availability and advantage of its human resources, particularly with regard to innovation and new product development (Lester et al., 2008).

The human involvement in product innovation has an impact on the productivity growth and industrial competitiveness, as shown by industries in Taiwan. The elements required by an industry to have superior values include the ability of its employees to continuously innovate. Through an innovation strategy, Taiwan has transformed itself into a country which ranks as the world's fourth-largest nanotechnology patent-holder (Tsai \& Wang, 2004). The impact of the innovation advantage owned by an industry includes market mastery and increased customer satisfaction (Sharma \& Kodali, 2008).

The human involvement in the innovative activities of industries can be seen in the process of the research and development of new products, which involves many individuals across disciplines, such as product design, manufacturing engineering, production engineering, environment engineering, and marketing. In the medium or large industries, individuals from across departments/functions join a team of product developers and are often separated from their home departments. Companies in almost all countries rely heavily on crossfunctional teams to develop new products. In 2000, as many as 77 percent of companies in the US, 67 percent in Europe and 54 percent in Japan employed cross-functional teams (Roberts, 2001).

The number of members of a product development team varies, ranging from a few to hundreds of members. For example, the development teams for IBM's computer development projects consist of an average of 200 members. The Yahoo! Portal was developed by 13 software engineers, who were split up into several small teams consisting of 1 to 3 members (Schilling, 2013). The product developers technical teams are integrated with each other and collaborate to decipher the complexities of product development, minimize risks, and reduce the impact of threats to their companies (Smith \& Offodile, 2008). Through collaboration, the members of a product development team would have the know-how (understanding) to meet the consumers' expectations and needs for the products.

A product will be successful in the market if it has the attributes that correspond to the consumers' expectations. A product's attributes are to ensure that the product can meet the needs, desires, and expectations of the buyers. By using a 'blue ocean strategy' approach, manufacturers can classify the priority of the development of the product's attributes which are innovative, and escape the competitors' attention (Kim \& Mauborgne, 2005). This strategy leads to a value 
innovation that can overpower the competitors without having to bleed in the 'red ocean', through the creation of product features that are unique and not owned by any competitors.

For SMIs, innovation and product development activities are tools to create new opportunities and help entrepreneurs to make changes, in the form of a new activity or a new service (Okwiet \& Grabara, 2013). Innovation, as the implementation of new ideas, creates new positive values for an organization. An innovation is defined as introducing something new, a thing newly entered, a novelty or a reform (Matic \& Jukic, 2012; Okwiet \& Grabara, 2013).

Innovation activities are proven to improve an enterprise's performance. Based on the study by Oke et al. (2007), an innovation positively correlates with the performance of industrial companies. The results of a measurement by Rosenbusch et al. (2011) show similar results. Through their meta-analysis study, Rosenbusch et al. (2011) suggests that innovation activities can improve the performance of a company, and are frequently found in SMIs. Although for some researchers, an innovation is considered to be complex, risky, and uncertain, but for others, it is considered a necessity, because the consumers' needs are constantly changing (Cooper, 2007). Through innovation, individuals who are the members of a product development team can create new opportunities for their company.

\section{Industrial Competitive Strategy}

Along with the development of technological advances and the increase in business competition, a strategy which is able to reposition manufacturers is needed to maintain the market and make a profit. The industries' need for competitive strategies has become a necessity due to constantly changing (dynamic) consumer needs. An industrial strategy is a strategic step taken by an organization to maintain its customers' satisfaction with its services or products' quality. The concept of an industrial strategy was first introduced by Skinner in 1969, who defined it as competing through manufacturing capabilities (Dangayach \& Deshmukh, 2001). Cox and Blackstone (1998) define industrial strategy as "a collective pattern of decisions that acts upon the formulation and deployment of manufacturing resources. To be most effective, the manufacturing strategy should act in support of the overall strategic direction of the business and provide for competitive advantages" (Laosirihongthong \& Dangayach, 2005: 133).

An industrial competitive strategy is an effort, undertaken by an industry, to win the competition in its target market by providing advantage values in the competition, analyzing the ability of competitors, and implementing an effective marketing strategy (Kotler \& Armstrong, 2012). A competitive strategy is a business action approach conducted by a management team, based on consumers' needs, in order to compete with other organizations/companies, with the aim of improving a company's growth. The application of a competitive strategy should be directed at a company's development priorities and the market's situation, in which the identification of strategies can be done in a proactive and reactive manner. The implementation of the strategy should take into account the strengths, weaknesses, opportunities and threats (Thompson et al., 2012).

The aims of implementing a competitive strategy are to: (1) Establish the right positioning; (2) maintain loyal customers; (3) gain new market share; (4) maximize sales; and (5) create effective business performance (Kotler \& Armstrong, 2012). A strategy implementation in an industrial company will influence the direction of the organization's development, production processes, human resources' development, corporate culture and the technology to be used (Mckeown \& Philip, 2003). A good strategy implementation will contribute to cost reductions, quality improvements, the provision of resources, and the company's future business objectives, primarily related to the variables of quality, delivery, flexibility, and cost (Dangayach \& Deshmukh, 2001). An effective strategy implementation is proven to improve a company's performance.

The application of a competitive strategy consists of three stages: (1) Competitive priori- 
ties, i.e. determining the corporate priorities, represented by the variables of cost, quality, flexibility and delivery of the product; (2) manufacturing objectives, i.e. determining the direction of corporate development, with the emphasis on cost, time and quality which would have an impact on the corporate performance; and (3) an action plan in the form of program improvements and the achievement of the corporate operational objectives (Takala et al., 2007). To run an effective strategy, there are five phases to be followed: (1) Developing a visionary strategy; (2) setting clear goals; (3) describing a strategy in the form of detailed visions and purposes; (4) implementing and executing the chosen strategy; and (5) monitoring the performance and evaluating the strategy (Thompson et al., 2012).

Some industrial competitive strategy models, e.g. Porter's (1998) competitive strategy model, employ three generic strategies, including costs, differentiation, and focuses. Meanwhile, a competitive strategy model developed by Thompson et al. (2012) employs four generic strategies, including being a low-cost provider, differentiation, best-cost provider, and focused or niche market based on cost. The strategy's implementation by SMIs can be a cycle of the Continuous Strategic Improvement (CSI) as shown in Figure 1.

A competitive strategy applied to a company has to adjust to the type of market or the customers served (Askar \& Mortagy, 2007). The strategy is also required to consider the priorities and direction of the company's development. A strategic priorities model, proposed by Barad and Gien (2001), describes the relationships between the competitive strategy and competitive advantage of SMIs and the ability of the employees in the company (human advantage), in which the competitive advantage variable is represented by price, delivery, quality, and variety, while the human advantage variable is represented by the employees' involvement.

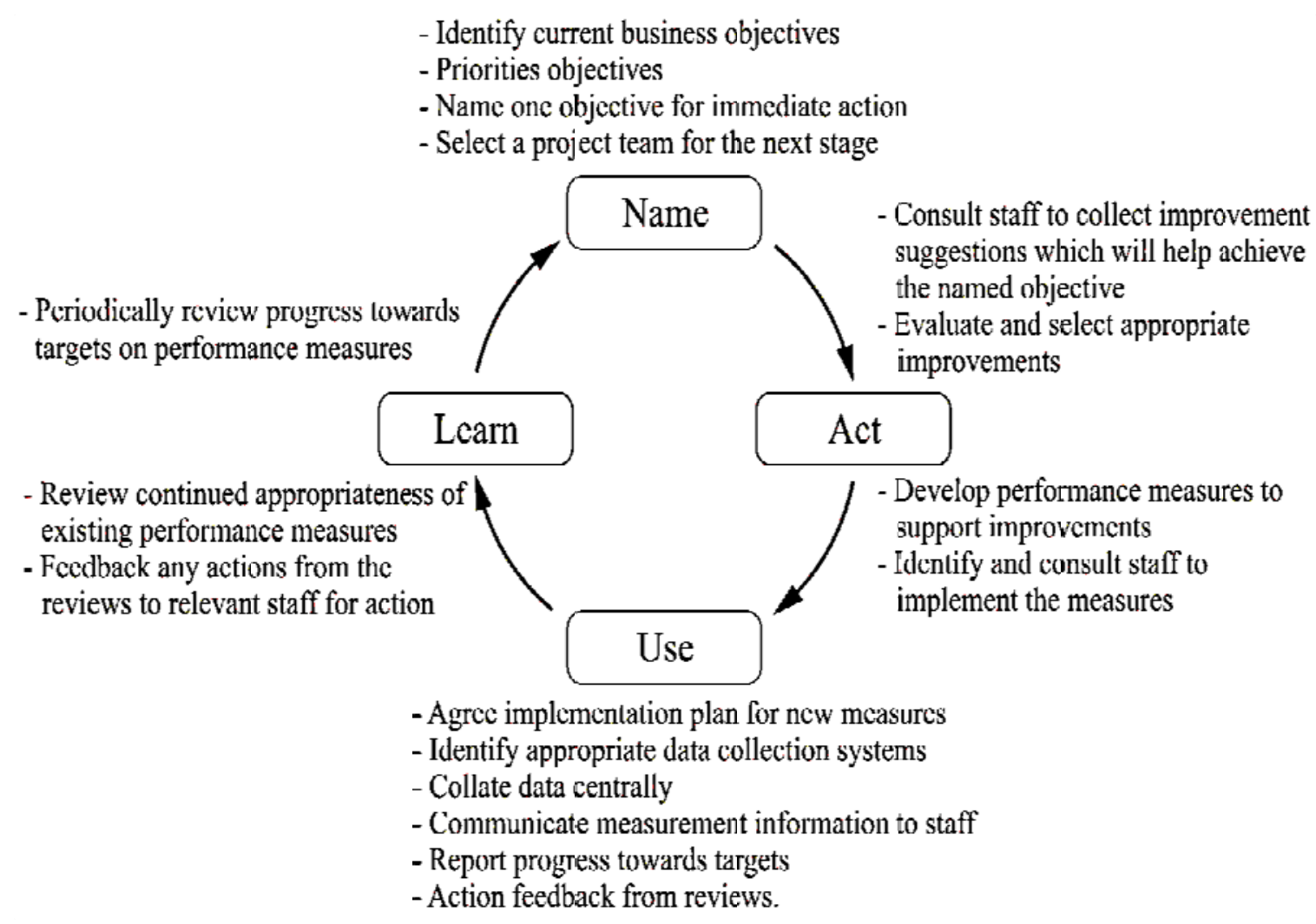

Figure 1. The CSI Strategy for SMIs (Smith \& Smith, 2007) 
A strategy framework to achieve a competitive advantage is also explained by Askar \& Mortagy (2007) using six variables, including: (1) Quality, defined as the company's ability to produce products/services in accordance with customer expectations through product-based, user-based, manufacturing-based or value-based approaches; (2) cost, defined as the ability to obtain benefits through lower prices and service costs; (3) delivery, defined as the ability to serve the market quickly and reliably; (4) flexibility, defined as the ability to respond to changes in the market environment by taking into account the technological flexibility and product flexibility; (5) service, defined as the ability to serve consumers during the sales (after-sale service) and product support; and (6) innovativeness, defined as the ability to develop and introduce new products, including production processes and technologies, used to create new market opportunities.

Through its in-depth literature search, this study explored the variables which influence the competitive strategy of industries (especially SMIs), including the competitive advantage variable and human advantage variable, as well as investigating the influence of these variables on the competitive strategy of the industry in a whole.

\section{Research Model and Hypotheses}

A research model is a conceptual model that describes the relationship, linkage, and interaction between certain variables, as part of a study or research project. A model's constituent variables are derived from a theoretical concept, developed by previous experts or researchers and stem from the new ideas to be tested and investigated (Sekaran \& Bougie, 2010). The phase where a theoretical concept is developed into a research model is essential, because this phase describes the relationship of the variables in a research model. The relationship between variables must meet the following criteria: Parsimonious and theoretically justifiable, so as to produce a correlation matrix (Hair et al., 2010).

Variables in this study's model were derived from previous studies variables, consisting of construct variables (latent variables) and manifest variables (indicators). A construct variable is an abstract concept that cannot be measured directly (unobserved variable), while a manifest variable is an abstract concept that can be directly measured (observed variable). Manifest variables are measured by the answers to questions in a questionnaire using a Likert scale (Ghozali, 2013). Based on the results of the in-depth literature search, this study found two dominant variable groups which affected the industrial strategy, particularly for the SMIs, including competitive advantage and human advantage. Both variables are categorized as the construct variables, while the manifest variables are derived from these two variables. A search using the keywords "industrial strategy", "competitive advantage" and "human advantage" found six construct variables namely: Cost, delivery, quality, variety, know-how, and innovativeness. The six construct variables are categorized as the independent variables $\mathbf{X} \boldsymbol{i}$, while the dependent variables $\mathbf{Y}$ are the industrial strategy.

Some of the literature sources reviewed are trusted sources. Besides this, the process of the literature search used the keywords "industrial strategy", "competitive advantage", and "human advantage". All these search strings were combined using the Boolean "AND". The process of the literature search was conducted through a Systematic Literature Review (SLR) by referring to the Kitchenham \& Charters (2007) scheme, where their literature review was done through three main phases - starting with collecting references, selecting the references suitability based on the criteria, and selecting the main references used in the literature study. The SLR steps are summarized in Figure 2.

The research variables derived from previous studies were then compiled into a table of model constituent specifications as outlined in Table 3. 
Step $0(n=64)$

Collecting references from electronic articles

\begin{tabular}{c}
$\begin{array}{c}\text { Step 1 (n=53) } \\
\text { Identifying relevant references } \\
\text { (according to title criteria) }\end{array}$ \\
\hline $\begin{array}{c}\text { Step 2 }(\mathbf{n}=\mathbf{3 6}) \\
\text { Relevant studies identification based on defined criteria } \\
\text { (according to tittles, abstracts, and keywords) }\end{array}$ \\
\hline
\end{tabular}

Step $3(n=31)$

Primary studies after quality assessment

Figure 2. Steps to Reviewing the Literature

Table 3. The Research Model's Constituent Variables

\begin{tabular}{|c|c|c|}
\hline Construct Variables & Manifest Variables (indicators) & References \\
\hline $\mathrm{X} 1$ Cost & $\begin{array}{ll}\text { X1.1 } & \text { Low cost } \\
\text { X1.2 } & \text { Volume added cost } \\
\text { X1.3 } & \text { Quality cost } \\
\text { X1.4 } & \text { Activity-based measurement } \\
\text { X1.5 } & \text { Continuous improvement } \\
\text { X1.6 } & \text { Lean manufacturing }\end{array}$ & $\begin{array}{l}\text { Phusavat \& Kanchana (2007), Gonzalez \& } \\
\text { Vazquez (2007), Askar \& Mortagy (2007), } \\
\text { Takala et al. (2007), Porter (1998), } \\
\text { Laosirihongthong \& Dangayach (2005), } \\
\text { Barad \& Gien (2001), Dangayach \& } \\
\text { Deshmukh (2005) }\end{array}$ \\
\hline X2 Delivery & $\begin{array}{ll}\text { X2.1 } & \text { Fast delivery } \\
\text { X2.2 } & \text { On agreed time } \\
\text { X2.3 } & \text { Right quality } \\
\text { X2.4 } & \text { Right amount } \\
\text { X2.5 } & \text { Dependable promises } \\
\text { X2.6 } & \text { Supply chain mgt. } \\
\text { X2.7 } & \text { Dependable delivery } \\
\text { X2.8 } & \text { Delivery speed } \\
\end{array}$ & $\begin{array}{l}\text { Laosirihongthong \& Dangayach (2005), } \\
\text { Phusavat \& Kanchana (2007), Askar \& } \\
\text { Mortagy (2007), } \\
\text { Barad \& Gien (2001), Dangayach \& } \\
\text { Deshmukh (2005), Sharma \& Kodali (2008) }\end{array}$ \\
\hline X3 Product Quality & $\begin{array}{ll}\text { X31 } & \text { Low defect rate } \\
\text { X3.2 } & \text { Product performance } \\
\text { X3.3 } & \text { Product reliability } \\
\text { X3.4 } & \text { Environmental aspect } \\
\text { X3.5 } & \text { Certification } \\
\text { X3.6 } & \text { Conformance quality } \\
\text { X3.7 } & \text { Product durability } \\
\text { X3.8 } & \text { Design quality }\end{array}$ & $\begin{array}{l}\text { Dangayach \& Deshmukh (2005), } \\
\text { Phusavat \& Kanchana (2007), } \\
\text { Takala et al. (2007), Sharma \& Kodali } \\
\text { (2008), Laosirihongthong \& Dangayach } \\
\text { (2005), Gonzalez \& Vazquez (2007), Barad \& } \\
\text { Gien (2001) }\end{array}$ \\
\hline X4 Product Variety & $\begin{array}{ll}\text { X4.1 } & \text { Design adjustment } \\
\text { X4.2 } & \text { Volume changes } \\
\text { X4.3 } & \text { Mix changes } \\
\text { X4.4 } & \text { Broad product line } \\
\text { X4.5 } & \text { Flexible processes } \\
\text { X4.6 } & \text { Design changes } \\
\text { X4.7 } & \text { New product introduction } \\
\text { X4.8 } & \text { Product customization } \\
\end{array}$ & $\begin{array}{l}\text { Sharma \& Kodali (2008), Phusavat \& } \\
\text { Kanchana (2007), Askar \& Mortagy (2007), } \\
\text { Takala et al. (2007), Laosirihongthong \& } \\
\text { Dangayach (2005), Dangayach \& Deshmukh } \\
\text { (2005), Porter (1998), Gonzalez \& Vazquez } \\
\text { (2007), Barad \& Gien (2001) }\end{array}$ \\
\hline X4 Product Variety & $\begin{array}{cl}\text { X4.9 } & \text { Product flexibility } \\
\text { X4.10 } & \text { Volume flexibility }\end{array}$ & \\
\hline X5 Know How & $\begin{array}{ll}\text { X5.1 } & \text { Knowledge management } \\
\text { X5.2 } & \text { Creativity } \\
\text { X5.3 } & \text { Continuous learning } \\
\text { X5.4 } & \text { Problem-solving skill } \\
\text { X5.5 } & \text { Training /education } \\
\text { X5.6 } & \text { Research \& development }\end{array}$ & $\begin{array}{l}\text { Phusavat \& Kanchana (2007), Takala et al. } \\
\text { (2007), Barad \& Gien (2001), } \\
\text { Laosirihongthong \& Dangayach (2005), Kim } \\
\text { \& Mauborgne (2005), Schilling (2013), Smith } \\
\text { \& Offodile (2008) }\end{array}$ \\
\hline
\end{tabular}


Table 3. The Research Model's Constituent Variables (Cont.)

\begin{tabular}{ccll}
\hline Construct Variables & \multicolumn{2}{c}{ Manifest Variables (indicators) } & \multicolumn{1}{c}{ References } \\
\hline X6 Innovativeness & X6.1 & Create new market & Okwiet \& Grabara (2013), Askar \& Mortagy \\
& X6.2 & Introduce new product & (2007), Phusavat \& Kanchana (2007), Sharma \\
& X6.3 & Develop new technology & \& Kodali (2008), Barad \& Gien (2001), \\
& X6.4 & Intellectual properties & Schilling (2013), Kim \& Mauborgne (2005), \\
& X6.5 & Expand foreign market & Lester et al. (2008), Matic \& Jukic (2012) \\
& X6.6 & Implement new technology & \\
\hline Y Industrial Strategy & Y1 & Robustness & \\
& Y2 & Technology & Mckeown \& Philip (2003), Takala et al. \\
& Y3 & Supply chain availability & (2007), Dangayach \& Deshmukh (2005), \\
& & & Gonzalez \& Vazquez (2007), Lester et al. \\
& & & (2008), Laosirihongthong \& Dangayach \\
& & Smith (2007), Barad \& Gien (2001), \\
& & Kotler \& Armstrong (2012), Thompson et al. \\
& & (2012) \\
\hline
\end{tabular}

Table 3 describes three keywords which are studied in more depth, namely industrial strategy, competitive advantage, and human advantage. These are compiled into a research model. The model of the relationship between these three key variables is presented in Figure 3 and described by the function:

$$
\begin{gathered}
\text { Industrial Strategy }=\mathrm{f} \text { (Competitive Advan- } \\
\text { tage, Human Advantage) }
\end{gathered}
$$

The research's structural model explains the relationship between the variables, thus generating the following research questions: (1)
Does the competitive advantage affect the industrial strategy? (2) Does the human advantage affect the industrial strategy? (3) How much do these two variables affect the industrial strategy? These research questions are arranged in the following hypotheses:

$\mathrm{H}_{1}$ : Competitive advantage affects industrial strategy.

$\mathrm{H}_{2}$ : Human advantage affects industrial strategy.

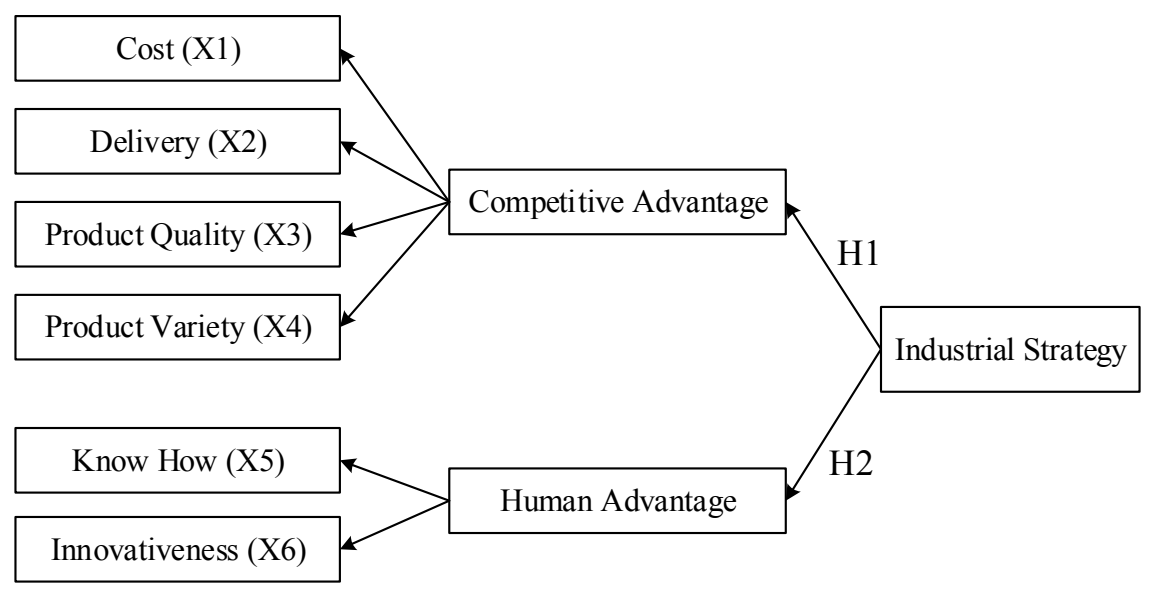

Figure 3. The Research Model and Hypotheses 


\section{RESULTS AND ANALYSIS OF THE RESEARCH}

\section{Variables Measurement}

Data in this study were processed using three types of software, including Microsoft Excel, SPSS, and AMOS. Microsoft Excel was used to tabulate the collected data. The SPSS software was used to test the validity and reliability of the model, while the AMOS software was used to build the model's structure using Structural Equation Modeling (SEM).

The SEM method was selected for this study due to its ability to explain and examine the relationship between complex variables, both recursive and non-recursive, in order to obtain an overall picture of the model being studied. The rule of thumb that should be met with an SEM model is that the model cannot be constructed without the underlying theories, because the theories affect the overall structure of the model and explain the relationship/ correlation between the variables making up the model. The theories and literature underlying the SEM model are applied to portray the dependency and correlational (covariance) relationships between the variables in a research model (Hair et al., 2010).

The variables measurement in this study used a Likert scale, ranging from 1 (very unimportant) to 5 (very important). The variables measurement was done through interviews and questionnaires distributed to the respondents, in accordance with the predetermined criteria, i.e. SMIs that employ a maximum number of 99 employees.

\section{Pre-test}

Prior to the questionnaires' distribution, preliminary research, in the form of a pre-test, was first performed to see whether the measuring instrument (questionnaire) was in conformity with the objectives of the research. There were ten respondents involved in the pretest, including academics, SMI owners, and government staff. Selection of the three stakeholders is considered important because, according to a study by Massa and Testa (2008), there are differences in the three parties' perceptions of the SMI model (triple helix). By involving these three elements as the pre-test respondents, the research can build a balanced and representative model.

Questions which were found to be invalid may indicate that those questions did not measure the level of the respondents' desires. Therefore, such questions were omitted or revised in terms of their sentence structure. The responses to the pre-test were then used to revise the sentence structure and the form of the questions in the questionnaires to be distributed to the SMIs.

\section{Unit of Analysis}

The unit of analysis in this study was the SMIs in Gorontalo Province which had been in business for at least three years, and produced a product (not a service company). The respondents included 100 owners or managers (or supervisors) of the SMIs, consisting of 81 men and 19 women. Each SMI was only represented by one (1) respondent. Descriptively, the respondents' characteristics are described in Table 4.

Table 4. The Respondents' Characteristics

\begin{tabular}{lll}
\hline Gender & Male & $: 81$ respondents \\
& Female & $: 19$ respondents \\
Age & $<25$ yo & $: 21 \%$ \\
& $26-35$ yo & $: 30 \%$ \\
& $36-45$ yo & $: 26 \%$ \\
& $46-55$ yo & $: 15 \%$ \\
& $>55$ yo & $: 8 \%$ \\
Formal & Primary/ Junior High & $: 26 \%$ \\
education & Senior High & $: 59 \%$ \\
& Diploma & $: 7 \%$ \\
& Undergraduate & $: 7 \%$ \\
& Postgraduate & $: 1 \%$ \\
\hline
\end{tabular}

With a total of 100 respondents, the research data was quite representative because the sample adequacy requirement was already met. The sample size in the SEM model generally numbers 100-200 samples, wherein the larger the sample size is, the more sensitive the model is (Hair et al., 2010). 
This study was conducted in Gorontalo Province since this new province did not have a blueprint for the development of its industries. This study, therefore, could provide the local government's policy makers and stakeholders with recommendations for the direction industrial development in the province should take. The output of this study could be used as one of the grand strategies for the SMIs' empowerment, in order to increase economic growth, create jobs, and improve the competitiveness of the region. The industries serving as the research sample were those included in the mainstay subsectors of the Indonesian Ministry of Industry, including ISIC 31 (food, beverages, and tobacco), ISIC 32 (textiles), ISIC 33 (wood, bamboo, rattan, and furniture), and ISIC 36 (non-metal mining industries) (Lasalewo, 2012).

SMIs in Gorontalo Province have similar characteristics to those in the other regions of Indonesia (i.e. those dominated by food, beverages, and crafts industries) so that this model could also be applied in the other regions. Based on the secondary data, the growth rate of SMIs in Gorontalo Province increased significantly, the number of units having increased by 17.48 percent per year, and the number of people in employment rose by 16.62 percent per year (Koperindag, 2007). In terms of the quantity, the number of SMIs in Gorontalo Province dominates that of the existing industries and creates on average as many as 31.5 to 100.4 jobs per industry (Bappeda, 2007).

\section{The Research Structural Model}

The research model of the relationships between the construct variables (latent variables), i.e. competitive advantage and human advantage, consists of variables X1 (cost); X2 (delivery); X3 (product quality); X4 (product variety); X5 (know-how) and X6 (innovativeness), and is presented in Figure 4. The relationships also illustrate the linear relationship between the dependent variables $\mathbf{Y}$ (endogenous), i.e. the industrial strategy variable, and the independent variables $\mathbf{X}$ (exogenous), i.e. competitive advantage and human advantage.

\section{Normality Size}

The normality size is an output to examine whether the research data have a multivariate normal distribution or not, which serves as the condition of assumption that must be met. The normality size of the research data was measured from the value of the Critical Ratio (CR), which is a representation of skewness or kurtosis. The normality evaluation was done by using a critical ratio for skewness of \pm 2.58 at the 0.01 significance level. The data shows a normal distribution if the critical ratio for skewness is below the absolute value of 2.58 (Hair et al.,

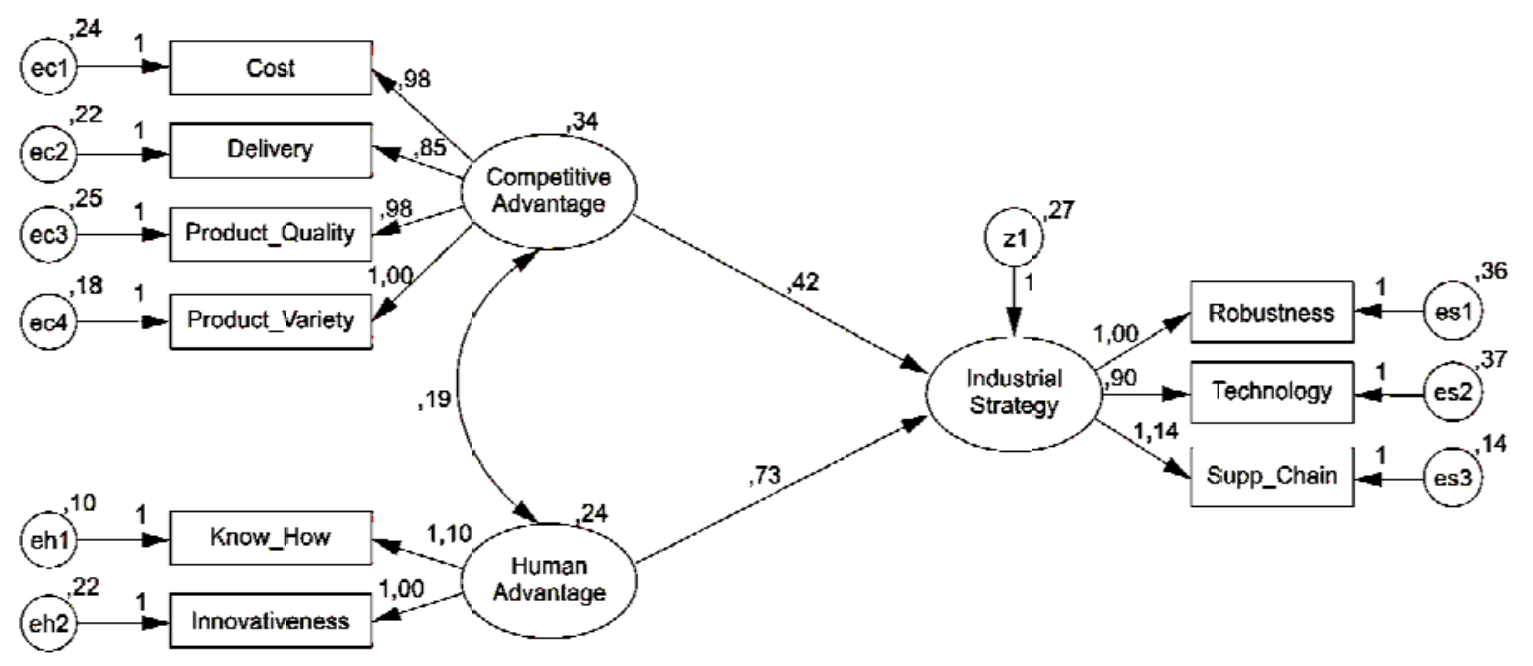

Figure 4. The Research Structural Model (AMOS Output) 
2010). The measurement results of this study indicate that all the data items are normally distributed.

\section{Outlier}

An outlier is an observation on an item of data that has unique characteristics, which look very different from other observations, and appears in an extreme value, either for a single variable or for combined variables. The multivariate outliers can be detected by observing the Mahalanobis distance value (Hair et al., 2010). The Mahalanobis distance in this study amounted to 27.88. The results of the data's processing show no Mahalanobis values higher than 27.88 , so it can be concluded that there is no outlier in the research data.

\section{Validity}

The construct validity of a research model is to measure how much the measurement theory is able to give confidence in the indicator size taken from the sample, and to describe the actual conditions in a population. The validity of a model can be seen from the value of goodness- of-fit (Hair et al., 2010). Assessing the goodnessof-fit is a major goal in a structural equation, and is to determine how well the hypothesized model fits the data sample. In this study, the values of goodness-of-fit are presented in Table 5, where they are all found to fit the data.

As shown in Table 5, the results of goodness-of-fit testing using several index indicators such as CMIN/DF, GFI, and TLI indicated that all the indicators (goodness-of-fit) fit the overall model. In conclusion, the model can be accepted.

\section{Reliability}

A reliability test was undertaken, to determine the reliability of the measuring instruments used in this study. It was calculated using Cronbach's alpha. The variables are said to be reliable if they have a value above 0.6 (Hair et al., 2010). From processing the data, it was known that the six variables are all reliable since their Cronbach's alpha values are all above 0.6 . The results of the variables' reliability test are presented in Table 6 .

Table 5. The Values of Goodness-of-fit Index

\begin{tabular}{cccc}
\hline Goodness-of-Fit & Analysis Results & Cut-off Value & Remark \\
\hline$\chi^{2}$-Chi-Square & 33.72 & Expected to be small & Fit \\
Probability & 0.09 & $\geq 0.05$ & Fit \\
CMIN/DF & 1.41 & $\leq 2$ & Fit \\
GFI & 0.93 & $\geq 0.90$ & Fit \\
AGFI & 0.88 & $\geq 0.90$ & Marginal \\
TLI & 0.97 & $\geq 0.90$ & Fit \\
NFI & 0.93 & $\geq 0.90$ & Fit \\
CFI & 0.98 & $\geq 0.95$ & Fit \\
RMSEA & 0.06 & $\leq 0.08$ & Fit \\
\hline
\end{tabular}

Table 6. The Variables' Reliability Test Results

\begin{tabular}{lcc}
\hline \multicolumn{1}{c}{ Construct Variables } & Number of Indicators & Cronbach's Alpha Values \\
\hline Cost & 6 & 0.904 \\
Delivery & 8 & 0.927 \\
Product Quality & 8 & 0.931 \\
Product Variety & 10 & 0.946 \\
Know-How & 6 & 0.881 \\
Innovativeness & 6 & 0.916 \\
\hline
\end{tabular}




\section{Multiple Regression Analysis}

A multiple regression analysis is a statistical technique used to estimate the relationship between one metric dependent variable and several metric or non-metric independent variables (Hair et al., 2010). It is different from the correlation analysis which only generates correlation values and the strength of a relationship between the variables. Meanwhile, the multiple regression analysis analyzes the strength of the influence of the independent variables on the dependent variables.

This study aimed to determine the overall effect of competitive advantage and human advantage on industrial strategy (corporate strategy). Based on the results of the data processing, the value of the coefficient of determination, as indicated by the squared multiple correlation $\left(R^{2}\right)$, is 0.402 , and the value of the adjusted R-square is 0.389 . The value of $\mathrm{R}$ square indicates the extent to which the independent variables (variables $X_{n}$ ) or construct variables (Table 3) represent or measure the research model, while the adjusted R-square is used to measure how much the level of confidence in the independent variables can measure the predictive power of the model. In addition, the analysis results indicate an $\mathrm{F}$ count value of 32.56, with a significance value of 0.00 (accepted limit of significance, if $p<0.05$ ). The results of this analysis suggest that competitive advantage and human advantage together influence the industrial strategy.

\section{Hypotheses Testing Results}

The industrial strategy's relationships with competitive advantage and human advantage are summarized in Table 7.
The evaluation results in Table 7 indicate that the competitive advantage variable has a significant and positive effect on the industrial strategy variable. This is evidenced by a $C R$ value of 2.14 with a $p$ significance value of 0.032 (significance limit, if $p<0.05$ ). The human advantage value also has a positive and significant impact on the industrial strategy, as evidenced by a $C R$ value of 3.00 with a significance value of 0.003 . As indicated by these values, both the human advantage variable and competitive advantage variable in this study suggest that the competitive advantage and human advantage significantly support the industrial strategy.

The results in Table 7 suggest that the competitive advantage, including production costs, improvements to the product's quality, continuous improvements to manufacturing, quick and timely product delivery, and product designs that fit the consumers' needs, has a significant influence on the development strategy of SMIs in Gorontalo Province.

In the context of human advantage, the development of the know-how aspects for the SMIs' entrepreneurs (e.g. developing business management skills, holding training, developing problem-solving skills) and innovation skills aspects (e.g. the ability to create market opportunities, creating new products and technologies, and market expansion) should be part of the development strategy for the SMIs in Gorontalo Province. These skills of competitive advantage and human advantage must be a concern and a benchmark for the successful development of the SMIs in the province.

Table 7. Hypotheses Testing Results

\begin{tabular}{lccccc}
\hline \multicolumn{1}{c}{ Hypotheses } & Estimate & S.E. & $\mathrm{CR}$ & $p$ & Remark \\
\hline Industrial strategy $\leftarrow$ competitive advantage & 0.419 & 0.195 & 2.14 & 0.032 & $\mathrm{H}_{1}$ is supported \\
Industrial strategy $\leftarrow$ human advantage & 0.731 & 0.243 & 3.00 & 0.003 & $\mathrm{H}_{2}$ is supported \\
\hline${ }^{*}$ CR (Critical Ratio) for normal distribution evaluation; & & & & \\
*significance limit, if $p<0.05$ & & & & &
\end{tabular}


The results in Table 7 also indicate that the construct variables and indicators in Table 3 can be outlined/manifested into a short-term (5 years) and long-term (20 years) development plans for the SMIs in the province. In line with this, according to Bappeda (2007), the regional development strategy (including the SMIs sector) can be created once there are adequate development elements available, i.e. an efficient government bureaucracy, adequate infrastructure, political stability, access to financing, and the availability of educated labor.

\section{CONCLUSIONS AND DISCUSSION}

\section{Conclusions}

Based on the literature review, this study finds that an industrial competitive strategy is affected by a lot of variables and underlying conditions. In this study, industrial competitive strategy, which is expressed as the variable "industrial strategy" (dependent variable Y), is influenced by two dominant factors of $X$, i.e. competitive advantage and human advantage. These two dominant factors are developed into six construct variables (independent variables $\mathrm{X})$, including cost (X1), delivery (X2), product quality (X3), product variety (X4), know-how (X5) and innovativeness (X6). By deepening the literature discussions, the six construct variables are developed into 44 manifest variables (indicators) and generate a model for industrial competitive strategy which serves as the focus of this study.

The research model in this study is a conceptual model, which can generally be applied to industries in many regions. It illustrates the relationship and interaction between variables. In this study, the unit of analysis is the SMIs in Gorontalo Province which have run for a minimum of three years and produce products (not services). The selection of the location of this research was based on the consideration of the strategic role of SMIs in the development of Gorontalo Province. As a newly-established province, Gorontalo has not yet had a blueprint for its industrial development. Therefore, this study is expected to provide recommendations to the policymakers in Gorontalo Province, and be able to be used as one of the grand strategies for the empowerment of the local industries. The output of this study could also be used as an SMI policy model for other areas in Indonesia because, basically, the SMIs in Gorontalo have similar characteristics to those in other regions in Indonesia.

There were 100 respondents comprising of SMIs owners or managers (or supervisors), in which every SMI was only represented by one respondent. The sample size of 100 respondents is quite representative, since the sample adequacy requirement was already satisfied. Based on the normality test, in general the data are normally distributed, as indicated by the value of the Critical Ratio (CR) and no outliers were found (shown by the Mahalanobis distance).The results of the reliability test using Cronbach's alpha show that the coefficient values of all the construct variables are above 0.6 , which means they are quite reliable. Meanwhile, the validity level, measured using the goodness-of-fit index, indicates a fit value, because it is above the threshold for acceptance.

Based on the hypotheses testing results, $\mathrm{H}_{1}$ and $\mathrm{H}_{2}$ are supported $\left(\mathrm{H}_{1:}\right.$ Competitive advantage affects industrial strategy, and $\mathrm{H}_{2:}$ Human advantage affects industrial strategy). This means that the variables of competitive and human advantages obviously affect the industrial strategy. Based on the proposed model, in fact, both competitive advantage and human advantage affect 40.2 percent of the industrial strategy taken.

\section{Discussion}

The decision-making process, in the context of the application of industrial strategy is quite complex and complicated, as it involves many variables. The decision making for the development of SMIs is critical to the organizational profits and regional competitiveness, because SMIs comprise most of the existing business units in Indonesia. SMIs in Gorontalo Province have similar characteristics as those in other areas in Indonesia, so the results of this research 
can also be used to develop a similar model to be applied to other areas.

The results of the literature study found two variable groups which influence the industrial strategy i.e. competitive advantage and human advantage, which served as the construct variables in this study. Many studies have found conditions for a hyper-competitive analysis, as developed by D'Aveni (1998), using the 7S's framework (Hülsmann et al., 2008). This refers to an analysis that shows that each country/SMIs will be forced to think of an appropriate strategy, so that it can survive in very tough global competition. This strategy can be in the form of a sustained competitive advantage strategy, or a strategy whose core includes planning efforts and integrated operational activities.

Currently, Indonesia's competitiveness ranks $34^{\text {th }}$ out of 144 countries (World Economic Forum, 2015). This competitiveness can actually be improved through a review of its industrial strategy, policies, and development programs. Given that a lot of variables affect the industrial competitiveness, further research is necessary to determine the priorities for industrial development (especially in SMIs), such as employing the manifest variables (indicators) in Table 3 of this study, to measure the SMIs' competitive priorities in Indonesia. The results of measurements using these competitive priorities can be a reference to any indicators which need consideration in the development of SMIs in Indonesia.

\section{REFERENCES}

Askar, M., and Mortagy, A. K., 2007. "Assessing the Relative Importance of Competitive Priorities in Egyptian Companies". SAM Advanced Management Journal, 72 (3), 35-46.

Bappeda, 2007. Rencana Pembangunan Jangka Panjang Daerah (RPJPD) Provinsi Gorontalo Tahun 2007-2025 [Regional LongTerm Development Plan (RPJPD) of Gorontalo Province 2007-2025]. Gorontalo Province.

Barad, M., and Gien, D., 2001. "Linking Improvement Models to Manufacturing Strategies - a Methodology for SMEs and other Enterprises". International Journal of
Production Research, 39 (12), 2675-2695.

Cooper, R. G., 2007. "Doing it Right: Winning with New Products". Innovation Framework Technologies.

Dangayach, G. S., and Deshmukh, S. G., 2001. "Manufacturing Strategy: Literature Review and some issues". International Journal of Operations \& Production Management, 21 (7), 884-932.

Dangayach, G. S., and Deshmukh, S. G., 2005. "Advanced Manufacturing Technology implementation: Evidence from Indian Small and Medium Enterprises (SMEs)". Journal of Manufacturing Technology Management, 16(5), 483-496.

Ghozali, I., 2013. Model Persamaan Struktural: Konsep \& Aplikasi Dengan Program AMOS 21.0 (Cetakan V) [Structural Equation Modeling: Concept and Application With AMOS 21.0 Program (5th Edition)]. Semarang, Indonesia: Diponegoro University Publisher.

Gonzalez, B. U., and Vazquez, J. M. C., 2007. "The Strategic Influence of Structural Manufacturing Decisions". International Journal of Operation \& Production Management, 27(6), 605-626.

Hair, J. F., Black, W. C., Babin, B. J., and Anderson, R. E., 2010. Multivariate Data Analysis (7th ed.). New Jersey: PrenticeHall.

Hülsmann, M., Grapp, J., and Li, Y., 2008. "Strategic Adaptivity in Global Supply Chains -Competitive Advantage by Autonomous Cooperation". International Journal of Production Economics, 114 (1), 14-26.

Indonesian Ministry of Cooperatives and SMEs., 2012. Statistik Usaha Mikro, Kecil dan Menengah (UMKM) Tahun 2010-2011 [Micro, Small and Medium Enterprises (SMEs) Statistics 2010-2011]. Retrieved October 5, 2013, from www.depkop.go.id.

Kim, W. C., and Mauborgne, R., 2005. Blue Ocean Strategy: How to Create Uncontested Market Space and Make the Competition Irrelevant. Massachusetts: Harvard Business School Publishing Corporation.

Kitchenham, B., and Charters, S., 2007. Guidelines for performing Systematic Literature reviews in Software Engineering Version 2.3. EBSE Technical Report, 
University of Keele \& University of Durham. Durham, UK: University of Keele $\&$ University of Durham.

Koperindag, 2007. Rencana Strategi (Renstra) Dinas Koperasi, Perindustrian dan Perdagangan Tahun 2007-2012 [Strategic Plan (Renstra) of the Department of Cooperatives, Industry and Trade 20072012]. Gorontalo Province.

Kotler, P., and Armstrong, G., 2012. Principes of Marketing (14th ed.). New Jersey: Pearson Prentice Hall.

Laosirihongthong, T., and Dangayach, G. S., 2005. "A Comparative Study of the Implementation of Manufacturing Strategies in Thai and Indian Automotive Manufacturing Companies". Journal of Manufacturing System, 24 (2), 131-143.

Lasalewo, T., Subagyo, Hartono, B., and Yuniarto, H. A., 2015. Hubungan Antar Fenomena Dalam Kegiatan Pengembangan Produk: Suatu Tinjauan Literatur. [Relationships between Phenomena in Product Development Activities: A Literature Review]. In The National Seminar on Industrial Engineering: Sustainability and Humanity in Engineering,71-79. Yogyakarta: Industrial Engineering Department, Gadjah Mada University.

Lasalewo, T., 2012. Strategi dan Kebijakan Industri: Aplikasi pada Industri Manufaktur dan Jasa (Edisi II) [Strategies and Industrial Policy: Application in Manufacturing Industry and Services (2nd ed.)]. Bandung, Indonesia: Wahana Media Pustaka Publisher.

Lester, D. L., Parnell, J. A., and Menefee, M. L., 2008. "Organizational Life Cycle and Innovation Among Entrepreneurial Enterprises". Journal of Small Business Strategy, 19 (2), 37-49.

Massa, S., and Testa, S., 2008. "Innovation and SMEs: Misaligned Perspectives and Goals among Entrepreneurs, Academics, and Policy Makers". Technovation, 28 (7), 393407.

Matic, I., and Jukic, V., 2012. "Innovativeness and Business Performances: Empirical evidence from Bosnia and Herzegovina's Small-Sized Firms". The Journal of American Academy of Business, 18 (1), 198-206.
Mckeown, I., and Philip, G., 2003. "Business Transformation, Information Technology and Competitive Strategies: Learning to Fly". International Journal of Information Management, 23, 3-24.

Oke, A., Burke, G., and Myers, A., 2007. "Innovation types and Performance in growing UK SMEs". International Journal of Operations \& Production Management, 27 (7), 735-753.

Okwiet, B., and Grabara, J. K., 2013. "Innovations' Influence on SME's Enterprises Activities". Procedia Economics and Finance, 6 (13), 194-204.

Phusavat, K., and Kanchana, R., 2007. "Competitive Priorities of Manufacturing Firms in Thailand". Industrial Management \& Data System, 107 (7), 979-996.

Porter, M. E., 1998. Competitive Advantage: Creating and Sustaining Superior Performance. New York: Free Press.

Roberts, E. B., 2001. "Benchmarking Global Strategic Management of Technology". Research Technology Management, 44 (2), $25-36$

Rosenbusch, N., Brinckmann, J., and Bausch, A., 2011. "Is Innovation Always Beneficial? A Meta-analysis of the Relationship Between Innovation and Performance in SMEs". Journal of Business Venturing, 26, 441-457.

Schilling, M. A., 2013. Strategic Managemen of Technological Innovation (4th ed.). New York: McGraw-Hill Companies, Inc.

Sekaran, U., and Bougie, R., 2010. Research Methods for Business: A Skill Building Approach. John Wiley \& Sons Ltd Publication (5th ed.). West Sussex, United Kingdom: John Wiley \& Sons Ltd Publication.

Sharma, M., and Kodali, R., 2008. "Development of a Framework for Manufacturing Excellence". Journal of Measuring Business Excellence, 12 (4), 50-66.

Smith, A. D., and Offodile, O. F., 2008. "Strategic Importance of Team Integration Issues in Product Development Processes to Improve Manufacturability". Team Performance Management, 14 (5/6), 269292.

Smith, M. H., and Smith, D., 2007. 
"Implementing Strategically Aligned Performance Measurement in Small Firms". International Journal of Production Economics, 106, 393-408.

Sudaryanto, Ragimun, and Wijayanti, R. R., 2014. Strategi Pemberdayaan UMKM Menghadapi Pasar Bebas Asean [The SME Empowerment Strategies for Facing ASEAN Free Market]. www.kemenkeu. go.id, 1-32. Retrieved from http://www. perpustakaan.depkeu.go.id/FOLDERJURN AL/2014_kajian_pkem_Strategi Pemberdayaan UMKM.pdf.

Takala, J., Hirvela, J., Liu, Y., and Malindzak, D., 2007. "Global Manufacturing Strategies Require "Dynamic Engineers"? Case study in Finnish Industries". Industrial Management \& Data System, 107 (3), 326-344.

Tambunan, T., 2007. "Entrepreneurship Development: SMEs in Indonesia". Journal of Developmental Entrepreneurship, 12 (1), 95-118.
Thompson, A. A., Peteraf, M. A., Gamble, J. E., and Strickland, A. J., 2012. Crafting and Executing Strategy: The Quest For Competitive Advantage, Concepts and Cases (18th ed.). New York: McGraw-Hill Irwin.

Tsai, K. H., and Wang, J. C., 2004. "The Innovation Policy and Performance of Innovation in Taiwan's Technology-Intensive Industries". Problems and Perspectives in Management, 1, 62-75.

Wang, H., 2014. "Theories for Competitive Advantage". In Being Practical with Theory: A Window into Business Research, 33-43. Wollongong: University of Wollongong, Australia.

World Economic Forum, 2015. The Global Competitiveness Report 2014-2015. Retrieved February 2, 2015, from http://www3.weforum.org/docs/WEF Glob alCompetitiveness Report_2014-15.pdf.

Notice: The Journal of Indonesian Economy and Business including the Editors decline all errors and flaws found in this article. Authors are fully responsible for them. 